\title{
Kırşehir ilindeki sera ve yüksek tünellerin mevcut durumu üzerine bir araştırma
}

\section{A study on the current state of greenhouses and high tunnels in Kırşehir province}

\section{Sedat BOYACI}

Kırşehir Ahi Evran Üniversitesi, Ziraat Fakültesi, Biyosistem Mühendisliği Bölümü, Kırşehir

Sorumlu yazar (Corresponding author): S. Boyac1, e-posta (e-mail): sedat.boyaci@ahievran.edu.tr

\section{MAKALE BILLGISİ}

Alınış tarihi 04 Aralık 2017

Düzeltilme tarihi 25 Mayıs 2018

Kabul tarihi 28 Mayıs 2018

\section{Anahtar Kelimeler:}

Sera

Yüksek tünel

Yapısal özellikler

\begin{abstract}
ÖZ
Bu çalışmada, Kırşehir il merkezi ve ilçelerindeki seraların ve yüksek tünel işletmelerinin mevcut durumunun belirlenmesi amaçlanmıştır. Bu amaçla yörede sera ve yüksek tünel işletmelerinin bulunduğu ilçelerde anket çalışması yürütülmüştür. İncelenen 10 adet sera ve 15 adet yüksek tünel işletmesinde sera işletmelerinin \% 60'nın, yüksek tünel işletmelerinin ise \% 20 'sinin $0-5$ yıl arasında yetiștiricilik yaptığı ve ilde örtüaltı yetiștiricilik deneyiminin uzun yıllara dayanmadığı belirlenmiştir. İlde kurulan işletmelerin plan ve projesiz yapılardan oluştuğu ve işletmelerin çevreden görerek işletmelerini kurdukları belirlenmiştir. Bunun yanında yörede doğal havalandırmaya yardımcı olacak havalandırma açıklıklarının düşük olduğu belirlenmiștir. İlin sahip olduğu jeotermal kaynaklardan yalnızca bir adet sera işletmesinin yararlandığı, küçük aile işletmelerinin ise 1sıtmayı yalnızca bitkileri don tehlikesinden koruma amaçlı yaptığı ve ilk yatırım maliyetlerinin yüksek olması nedeniyle ucuz ve yenilenebilir bu enerji kaynağından yararlanamadığı belirlenmiştir. İlde gelişim içerisinde olan örtüaltı tarımında, üreticileri örtüaltı tarımı konusunda bilinçlendirmek ve gerekli teknik bilgilerin verilmesi amacıyla yayım faaliyetlerinin arttırılması gerekmektedir. Bunun yanında jeotermal enerji altyapı maliyetlerinin yetki kurum ve kuruluşlarca sağlanması koşuluyla bölgenin örtüaltı tarımına kazandırılması gerekmektedir.
\end{abstract}

\section{ARTICLE INFO}

Received 04 December 2017

Received in revised form 25 May 2018

Accepted 28 May 2018

\section{Keywords:}

Greenhouse

High tunne1

Structural properties

\begin{abstract}
In this study, it was aimed to determine the current state of the greenhouses and high tunnel enterprises in Kurșehir province center and its districts. For this purpose, a questionnaire was carried out in the districts of the province where greenhouse and high tunnel enterprises are located. Among 10 greenhouses and 15 high tunnel enterprises that were studied, it was found that $60 \%$ of the greenhouse enterprises, while $20 \%$ of the high tunnel enterprises carried out cultivation for 0-5 years and the greenhouse cultivation in the province does not date back a long time ago. It was determined that the enterprises established in the province are composed of unplanned and unprojected structures and they were established by observing the previous enterprises in their surroundings, and also that the ventilation openings that help natural ventilation in the area are low. It was determined that only one greenhouse enterprise benefited from the province's geothermal resources, whereas small-scale family-owned enterprises performed heating only to protect plants from frost threat and they could not make use of this inexpensive and renewable energy source because the initial investment costs are high. In order to raise awareness of the producers about the greenhouse cultivation, which is in progress, and to provide with the necessary technical information, it is essential to increase the publication activities. Additionally, it is necessary to bring in the province to greenhouse cultivation provided that the costs of geothermal energy infrastructure are financed by the authorized institutions and organizations.
\end{abstract}

\section{Giriş}

Birim alandan yüksek verim alınmasını sağlayarak küçük alanların marjinal olarak değerlendirilmesine olanak veren örtüaltı tarımı, aynı zamanda yıl içerisinde düzenli bir işgücü kullanımı sağlaması nedeniyle de ülkemizdeki en önemli tarımsal faaliyetlerden birisi haline gelmistir (Sevgican ve ark. 1990). Örtüaltı yetiştiriciliği, turfanda amaçlı alçak veya yüksek tünellerde de yapılsa mevsim dışı üretim amaçlı seralarda da yapılsa tarımın diğer bitkisel üretim kolları içerisinde birim 
alandan en fazla gelir sağlayan koludur. Bu nedenle günümüzde sürekli olarak alan ve üretim artışı ile birlikte teknolojik gelişim göstermektedir. Artan teknoloji ve üretici katılımıyla, bir sektör haline gelen ve büyük kazançlar getiren örtüaltı tarımının bu avantajlarından yararlanmak isteyen üreticilerin sayısı gün geçtikçe artmaktadır (Boyacı ve ark. 2016). Bu nedenle örtüaltı tarımı, ülkemizde ekolojinin olanak tanıdığ bölgelerden sonra sıcak su kaynaklarının bulunduğu bölgelerde de yayılım göstererek önemli bir ekonomik faaliyet özelliği kazanmıștır (Kadığlu 2013; Boyacı ve ark. 2016). Aynı zamanda bu bölgelerde yapılan örtüaltı faaliyetlerinin en büyük avantajı bitkileri sadece soğuk günlerde don tehlikesinde korunma amacıyla değil ucuz ve yenilenebilir enerji kaynakları sayesinde bitkileri y1l boyu uygun sicaklık değerlerinde tutarak verimde artış imkanıda sağlamasıdır.

İç Anadolu bölgesinde yer alan ve sahip olduğu karasal iklim ve jeotermal enerji kaynakları ile Kırşehir ili de örtüaltı tarımının avantajlarından yararlanmak isteyen illerimiz arasındadır. İlde 2016 yılı verilerine göre niteliklerine göre örtüaltı tarım alanları Çizelge 1'de verilmiştir. $\mathrm{Bu}$ alanlarda yetiştirilen Örtüaltı sebze ve meyve üretimi değeri ise toplam 4707 ton dur ve bu miktarın \% 99 u domates üretimidir (TÜIK 2017). İlde son yıllarda gelişen örtüaltı faaliyetleri ile birlikte örtüaltı tarımında nitelik ve üretim miktarı artmaktadır.

Çizelge 1. Kırşehir iline ait niteliklerine göre örtü altı tarım alanları.

Table 1. Greenhouse areas according to the qualifications in Kırşehir province.

\begin{tabular}{cccc}
\hline Plastik sera (da) & Yüksek tünel (da) & Alçak tünel (da) & Toplam (da) \\
\hline 224 & 28 & 6 & 258 \\
\hline
\end{tabular}

Örtüaltı üretimi açıkta yetiştiriciliğe göre daha fazla bilgi ve tecrübe isteyen bir tarımsal uğraştır. Ülkemizde seralar çoğu zaman yöre koşulları dikkate alınmadan, statik ve mukavemet hesaplamaları yapılmadan inşa edilmektedir. Bunun sonucunda, ya gereğinden çok ya da gereğinden az yap1 malzemesi kullanılmaktadır. Gereğinden çok malzeme kullanıldığında sera içi gölgeleme oranı artmakta, gereğinden az malzeme kullanılması durumunda ise kötü hava koşullarında yıkılmalar meydana gelmektedir (Üstün ve Baytorun 2003). Seralar rüzgâra, yağmura, dolu ve karlara, bitki hastalıklarına veya aşırı sıcaklığa karşı bitkileri korumak için kullanılan yapılardır. Bu yapıların tasarımı ve iç mikro klima kalitesini etkileyen en önemli iklim faktörleri ise sıcaklık, küresel güneş radyasyonu, yağış ve rüzgâr şiddetidir. $\mathrm{Bu}$ nedenle, yerel meteorolojik koşullar sadece seraların iç ortam klima değerlerine değil, aynı zamanda yapısal tasarımlarını da büyük ölçüde etkilemektedir. Sert hava koşulları, sera yapılarının başarısızlığının en yaygın nedenidir. Bu nedenle, sera tasarımında, yerel iklim ile ilgili düzenlemelere uymalıdır (von Elsner ve ark. 2000). Bir projeye bağlı olmadan kurulan sera yapılarında, kullanılan yap1 malzemeleri ve boyutları bakımından değişiklikler göstermektedir. Yapı malzemelerindeki bu farklılıklar ekonomik olmayan ve mukavemet yönünden yetersiz sera yapılarının ortaya çıkmasına neden olur. Gerekli yük ve mukavemet hesapları yapılmadan seçilen malzemeler ile inşa edilen seralarda bazı yapı elamanları zamanla işlevselliğini kaybetmektedir. Şiddetli dış etkiler (kar, rüzgâr vb.) neticesinde meydana gelen çökme neticesinde sera içerisindeki ürünün büyük bir bölümü ya da tamamı elden çıkarak ekonomik kayıplara neden olmaktadır (Dökmen ve Arıcı 1998).
İlde son yıllarda gelişmeye başlayan sera ve yüksek tünel işletmelerinin teknik ve yapısal yönden ileriki yıllarda karşılaşabilecekleri problemlerin önceden ortaya konulması ve bu hataların ortadan kaldırılması yetiştiricilikte yapısal sorunlardan kaynaklı verim kayıplarının da önüne geçilmesi bakımından önemlidir.

$\mathrm{Bu}$ çalışmada, Kırşehir ili Merkez ve ilçelerindeki sera ve yüksek tünel işletmelerinin teknik ve yapısal yönden özellikleri belirlenerek mevcut durumları ve sorunlarının saptanması ve bu işletmelerin karşılaştıkları sorunlara ilişkin çözüm önerilerinin ortaya konulması amaçlanmıştır.

\section{Materyal ve Yöntem}

Kırşehir ilinde 2017 yılının Haziran-Eylül aylarında yürütülen bu çalışmada, araştırma materyalini ilçelerdeki sera ve yüksek tünellerde yetiştiricilik yapan işletmeler oluşturmuş̧tur. $\mathrm{Bu}$ amaçla, ilk olarak Kırşehir ili tarım il ve ilçe müdürlükleri ile yapılan görüşmeler sonucu sera ve yüksek tünel yapılarının bulunduğu alanlar belirlenmiştir. Buna göre ilde sera ve yüksek tünel tarımı yapan işletmelerin Merkez, Çiçekdağı ve Kaman ilçelerinde bulunduğu belirlenmiştir. Anket çalışması yapılan Kırşehir ilinin ilçeleri ve konumu Şekil 1 'de verilmiştir.

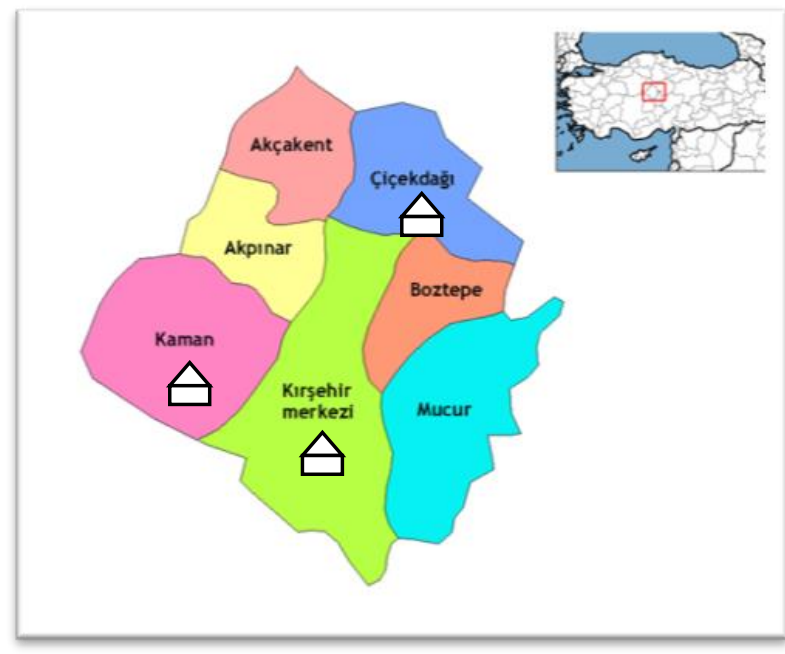

Şekil 1. Kırşehir ilinin ilçeleri ve konumu.

Figure 1. Provinces and location of Kırşehir.

$\mathrm{Bu}$ ilçelerde tespit edilen 10 adet sera ve 15 adet yüksek tünel olmak üzere toplam 25 adet işletme ile anket çalışması yapılmıştır. Anket sayısı ilde sera ve yüksek tünel işletmelerinin azlığ 1 ve mevcut bir kayıt sistemi bulunmaması nedeniyle tespit edilebilen tüm işletmeler ankete tabi tutulmuştur. Anket formları ile üreticilere; üretici, işletme, yapı ve üretim bilgileri ile havalandırma, gölgelendirme, soğutma, 1sıtma sistemleri ve karşılaştıkları sorunlar hakkında sorular sorularak ildeki mevcut duruma ilişkin bilgiler doğrudan/yüzyüze görüşme yoluyla toplanmıştır. Elde edilen bilgiler işletme sayısı üzerinden değerlendirilmiş ve sonuçlar rakamsal değerler ve yüzde (\%) oransal değer olarak çizelgeler ile sunulmuştur. Çalışmada işletme şekli aile işletmesi ve büyük işletmeler olarak iki ayrı gruba ayrılmıştır. Burada aile işletmesi yalnızca aile işgücü kullanılarak yetiştiricilik yapan işletmeleri, büyük işletmeler ise aile işgücü dışında mühendis, teknisyen, geçici ve daimi işçi istihdam eden işletmeler olarak tanımlanmıştır. 


\section{Bulgular ve Tartışma}

\section{1. Üretici ve işletmelere ait bilgiler}

Anket çalışması ile elde edilen üretici ve işletmelere ait bilgiler Çizelge 2'de verilmiştir. Anket yapılan işletmelere bakıldığında sera işletmelerinin \% 60'nın, yüksek tünel işletmelerinin ise \% 20 sinin $0-5$ y1l arasında yetiştiricilik yaptığı görülmektedir. Önceki yıllarda Antalya ili ve ilçelerinde yapılan çalışmalara bakıldı ğında, seracılık faaliyetlerinin, ikinci ve üçüncü kuşak aile bireyleri tarafindan yapıldığını ve işletme sahiplerinin deneyim sürelerinin 15 yıldan daha uzun olduğunu bildirmiştir (Çanakcı ve Akıncı 2007; Tüzel ve ark. 2010; Gale ve ark. 2014). Türkiye'nin güneyinde başlayan ve örtüaltı tarımının yoğun olarak yapıldığ Antalya ilinde üreticilerin büyük çoğunluğu örtüaltı yetiştiricilikte tecrübe sahibi iken seracılığın yeni gelişmeye başladığı Kırşehir ilinde sera ve yüksek tünelde yetiştiricilik açısından yeni oldukları söylenebilir. Ülkemizde tarım geleneksel ve alışkanlıklara bağlı olarak geliştiğinden örtüaltı yetiştiricilikte yeni olan yöre üreticilerinin yeni ve modern üretim teknikleri konusunda bilinçlendirilmesi, birim alandan alınan verimin arttırılması açısından oldukça önemlidir.

İlde seraların \% 50 sinin kişiye ait olduğu bunun yanında şirket ve kooperatife ait seralarında bulunduğu belirlenmiştir. Yüksek tünellerin ise \%93.33 ünün kişiye ait olduğu ve bu yapıların üzerinde bulunan arazinin sera işletmelerinin \% 50 sinin kendi arazisi üzerinde sera kurduğunu ve bu yapıların inşası için kredi kullandığı, yüksek tünellerde ise arazinin tamamının işletme sahiplerine ait olduğu ve yalnızca bir işletmenin bu yapıların inşaası için kredi kullandığ 1 belirlenmiştir (Çizelge 2). Emekli (2007), tarafından sera işletmelerinin kurulum aşamasında öz sermaye, banka kredisi ve teşvik kredisi kullanılarak inşa edildiği bildirilmiştir. Benzer şekilde Kırşehir ilinde de sera ve yüksek tünel işletmelerinin mülk veya kira olduğu ve öz sermaye veya kredi kullandıkları belirlenmiştir. Kaman ilçesinde tarım ilçe müdürlüğü tarafından genç çiftçileri destekleme projesi kapsamında kurulan iki adet sera ilçede seracılığın gelişmesi yanında genç nüfusun istihdama kazandırılması açısından da oldukça önemlidir. Bunun yanında kendi arazi ve öz sermayesi oranında yatırım yapan yöre üreticilerine sera alanlarının ve seracılığın gelişmesi için verilecek hibe ve teşvik kredilerinin arttırılması yöre ve ülke ekonomisi açısından oldukça önemlidir.

\section{2. İşletmelerin Yapısal Özellikleri}

\subsubsection{Issletmelerin proje ve kurulum bilgileri}

Anket çalışması ile elde edilen İşletmelerin proje ve kurulum bilgileri Çizelge 3 'de verilmiştir. Kırşehir ilinde incelenen sera işletmelerinin \% 70 inin yüksek tünellerin ise tamamının projesiz yapılar olduğu belirlenmiştir. İlde 3 adet işletmede yer alan seraların projeli olduğu ve işin uzmanı mühendislerden faydalanıldığ 1 belirlenirken diğer sera ve yüksek tünel işletmelerinde yapıların çevreden örnek alınarak veya işletme sahibinin kendi fikri veya önceki deneyimlerinden faydalanıldığ malzemelerinin sağlanma şekli olarak sera ve yüksek tünel işletmelerinin büyük bir kısmının malzemeyi kendisinin piyasadan aldığı, 2 adet yüksek tünelin ise kaymakamlık (kamu) tarafından verildiği ve sera konstrüksiyonunun herhangi bir ustaya yaptırıldığ 1 belirlenmiştir.

Çizelge 2. Üretici ve işletmelere ait bilgiler.

Table 2. Information on producers and enterprises.

\begin{tabular}{|c|c|c|c|c|c|}
\hline \multirow{2}{*}{ Üretici ve işletmelere ait bilgiler } & \multirow{2}{*}{ Cevap Sınıfi } & \multicolumn{2}{|c|}{ Sera } & \multicolumn{2}{|c|}{ Yüksek tünel } \\
\hline & & Üretici sayısı & $\%$ & Üretici sayısı & $\%$ \\
\hline \multirow{3}{*}{ İşletme şekli } & Aile işletmesi & 2 & 20.00 & 12 & 80.00 \\
\hline & Büyük işletme & 8 & 80.00 & 3 & 20.00 \\
\hline & Toplam & 10 & 100.00 & 15 & 100.00 \\
\hline \multirow{5}{*}{ Sera büyüklük grubu $\left(\mathrm{m}^{2}\right)$} & $0-500$ & 5 & 50.00 & - & - \\
\hline & $500-1000$ & 2 & 20.00 & - & - \\
\hline & $5000-20000$ & 2 & 20.00 & - & - \\
\hline & $20000-180000$ & 1 & 10.00 & - & - \\
\hline & Toplam & 10 & 100.00 & 0 & 0.00 \\
\hline \multirow{4}{*}{ Yüksek tünel büyüklük grubu $\left(\mathrm{m}^{2}\right)$} & $0-200$ & - & - & 8 & 53.33 \\
\hline & $201-400$ & - & - & 4 & 26.67 \\
\hline & $401-600$ & - & - & 3 & 20.00 \\
\hline & Toplam & 0 & 0.00 & 15 & 100.00 \\
\hline \multirow{5}{*}{$\begin{array}{l}\text { İşletme sahibinin seracılık yaptığı } \\
\text { süre (y1l) }\end{array}$} & $0-5$ & 6 & 60.00 & 3 & 20.00 \\
\hline & $6-10$ & 3 & 30.00 & 5 & 33.33 \\
\hline & $11-15$ & - & - & 4 & 26.67 \\
\hline & 15 'den fazla & 1 & 10.00 & 3 & 20.00 \\
\hline & Toplam & 10 & 100.00 & 15 & 100.00 \\
\hline \multirow{5}{*}{ Seranın mülkiyet durumu } & Kisiye Ait & 5 & 50.00 & 14 & 93.33 \\
\hline & Şirkete Ait & 1 & 10.00 & - & - \\
\hline & Kamu & 2 & 20.00 & 1 & 6.67 \\
\hline & Kooperatif & 2 & 20.00 & - & - \\
\hline & Toplam & 10 & 100.00 & 15 & 100.00 \\
\hline \multirow{3}{*}{ Seranın bulunduğu arazi } & Kira & 5 & 50.00 & - & - \\
\hline & Özmülk & 5 & 50.00 & 15 & 100.00 \\
\hline & Toplam & 10 & 100.00 & 15 & 100.00 \\
\hline \multirow{3}{*}{ Kredi kullanma durumu } & Kredi Kullanmış & 4 & 40.00 & 1 & 6.67 \\
\hline & Kredi Kulanmamış & 6 & 60.00 & 14 & 93.33 \\
\hline & Toplam & 10 & 100.00 & 15 & 100.00 \\
\hline
\end{tabular}


Çizelge 3. İşletmelerin proje ve kurulum bilgileri.

Table 3. Project and constructions informations of enterprises.

\begin{tabular}{|c|c|c|c|c|c|}
\hline \multirow{2}{*}{ İşletmelerin proje ve kurulum bilgileri } & \multirow{2}{*}{ Cevap Sinıfi } & \multicolumn{2}{|c|}{ Sera } & \multicolumn{2}{|c|}{ Yüksek tünel } \\
\hline & & Üretici sayısı & $\%$ & Üretici sayısı & $\%$ \\
\hline \multirow{3}{*}{$\begin{array}{l}\text { İşletmedeki seralar ve yardımcı yapıların } \\
\text { bir projesi var mı }\end{array}$} & Evet & 3 & 30.00 & - & - \\
\hline & Hayır & 7 & 70.00 & 15 & 100.00 \\
\hline & Toplam & 10 & 100.00 & 15 & 100.00 \\
\hline \multirow{4}{*}{$\begin{array}{l}\text { Varsa proje nereden sağlanmıştır/yoksa } \\
\text { nasıl kurulmuş }\end{array}$} & İ̀letme sahibinin kendi fikri & - & - & 9 & 60 \\
\hline & Çevreden örnek alınmış & 7 & 70.00 & 6 & 40 \\
\hline & Mühendis hazırlamış & 3 & 30.00 & - & - \\
\hline & Toplam & 10 & 100.00 & 15 & 100.00 \\
\hline \multirow{4}{*}{ Sera konstrüksiyonu nasıl inşa edilmiştir } & İşletmeci kendisi & 2 & 20.00 & 3 & 20 \\
\hline & Herhangi bir usta & 5 & 50.00 & 12 & 80 \\
\hline & Yapımcı firma & 3 & 30.00 & - & - \\
\hline & Toplam & 10 & 100.00 & 15 & 100.00 \\
\hline \multirow{4}{*}{$\begin{array}{l}\text { Konstrüksiyonda kullanılan malzemelerinin } \\
\text { sağlanma şekli }\end{array}$} & Yapımcı firma & 3 & 30.00 & - & - \\
\hline & Piyasan kendiniz aliyorsunuz & 7 & 70.00 & 13 & 86.67 \\
\hline & Kamu & - & - & 2 & 13.33 \\
\hline & Toplam & 10 & 100.00 & 15 & 100.00 \\
\hline
\end{tabular}

Araştırmada ele alınan 10 adet sera ve 15 adet yüksek tünel işletmesinin kapladığı alan yaklaşık $210392 \mathrm{~m}^{2}$ dir. Buna göre 0-500, 500-1000, 5000-20000, 20000-180000 $\mathrm{m}^{2}$ büyüklük grubu için ortalama sera alanı sırasıyla 270,1-825-11815$180000 \mathrm{~m}^{2}$ dir. Yüksek tüneller için 0-200, 201-400, 401-600 $\mathrm{m}^{2}$ büyüklük grubu için ortalama yüksek tünel alanı sırasıyla 107.8-323.7-534.8 $\mathrm{m}^{2}$ dir. Yörede seraların \% 50'si, taban alanı $0-500 \mathrm{~m}^{2}$ olan seralardan oluşurken yüksek tünellerin yaklaşık $\%$ 53'ü 0-200 $\mathrm{m}^{2}$ taban alanına sahiptir. Seralarda, verimin artabilmesi ve etkin bir üretim için kaliteli tohum, yetiştiricilik ve sulamanın gerekliliği kadar, yapının konstrüksiyon, mekanizasyon ve iklimlendirme yönünden de son derece etkin olması gerekmektedir (Güllüler 2007). İlde kurulan sera ve yüksek tünellerin plansız ve projesiz yapılması nedeniyle ileriki yıllarda yapısal kaynaklı verim kayıplarının yaşanması kaçınılmaz olacaktır. Bu nedenle ilde kurulacak yapılarda teknik bilgi ve iletişim amacıyla örtüaltı tarımı konusunda uzman kişi, kurum ve kuruluşlardan yardım alınması oldukça önemlidir.

\subsubsection{Issletmelerde kullanılan yapı malzemeleri ve boyutsal özellikleri}

Araştırma alanında incelenen seraların tamamında bireysel temellerin kullanıldığı belirlenmiştir. Buna göre temel boyutları $30 \times 30 \times 30 \mathrm{~cm}$ ile $100 \times 100 \times 80 \mathrm{~cm}$ derinliği arasında değişmektedir. Yüksek tünellerde ise $30 \times 30 \times 40 \mathrm{~cm}$ 'lik bireysel temeller yanında kolonların toprağa $30-40 \mathrm{~cm}$ arasında daldırma yapıldığı belirlenmiştir. Yağanoğlu (2013), kolon veya temel derinliğinin en az 45-50 cm ve toprak donma derinliğinden daha derin olması ve temellerin sürekli temel yapılması ve betonla pekiştirilmesinin uygun olduğunu bildirmiştir. İlde kurulan seraların büyük bir kısmında derinliklerin uygun değerlere olduğu ancak yüksek tünellerde buna dikkat edilmediği belirlenmiştir. Emekli ve ark. (2007) temel kullanılmayan işletmelerde sera kolonlarının $35-40 \mathrm{~cm}$ toprak derinliğine gömüldüğünü ve sera kolonlarının temel olarak kullanıldığ 1 seralarda, işletme sahipleri üretim sezonu içinde özellikle kış yağışlarının fazla olduğu dönemlerde seralarını su bastığını bildirmişlerdir. İlde kurulacak seralarda bu tür problemlerin yaratacağı verim kayıplarının yaşanmaması için kurulum aşamasında tedbir alınması son derece önemlidir.

İlde kurulan sera ve yüksek tünellerde kutu, boru, I, T ve L profillerinin kullanıldığ 1 bir yüksek tünel işletmesinde ise 8 mm'lik çelik demirin bükülmesi ile yapılmıştır. Seraların yapımında en çok kullanılan profil şekilleri I, T, L profil çelikleri ile kutu ve boru profillerdir (Yağanoğlu 2013). Ancak karasal iklime sahip ilde kar ve rüzgar yükü düşünüldüğünde kullanılan bu yapı malzemelerinin projesiz yapıldığından ileriki yıllarda geniş malzeme kullanımından gölgeleme, zayıf malzeme kullanıldığında ise devrilme ve yıkılmaya karşı emniyetsiz olacağı açıktır. TSE standartlarına göre rüzgar yükü değeri 0-8 m yüksekliğindeki yapılar için $\mathrm{q}=50 \mathrm{~kg} \mathrm{~m}^{-2}$ değeri verilmiştir ve bu değer $28 \mathrm{~m} \mathrm{~s}^{-1}$ rüzgar hızına denk gelmektedir. Ancak ilde esen en şiddetli rüzgar hızına bakıldığında bu değerin $34 \mathrm{~m} \mathrm{~s}^{-1}$ olduğu görülmektedir. Bu değerin karşılık geldiği rüzgar yükü değeri yaklaşık olarak $\mathrm{q}=80 \mathrm{~kg} \mathrm{~m}^{-2}$ dir. Kar yükü değeri olarak ta $P k o=80 \mathrm{~kg} \mathrm{~m}^{-2}$ olarak alınmalıdır. TSE verilen değerlerin sabit olmadığını, mahalli topografik şartlar nedeniyle değişik rüzgâr hızları oluşabileceğini ve değerlerin sapabileceğini bildirmiştir. $\mathrm{Bu}$ nedenle malzeme boyutlarının uzman yardımıyla boyutlandırılması oldukça önemlidir. Seraların enleri 5.54-12 m boyu 21-110 m, yan duvar yüksekliği 1-5.50m, mahya yüksekliği 2.10-6.20 m, kolonlar arası mesafe 2-3 m, yüksek tünellerin enleri $3-6.60 \mathrm{~m}$ boyu $13-40 \mathrm{~m}$, yükseklikleri $1.60-3.0 \mathrm{~m}$, kolonlar aras1 mesafe $0.80-2 \mathrm{~m}$ arasında değişmektedir. Sera boyunun fazla uzun olması 1sıtma ve havalandırma yönünden, uzunluğu az olan seralar ise işçilerin çalışması yönünden sakıncalı olabilir. $\mathrm{Bu}$ nedenlerle genişliğin $(9-12 \mathrm{~m})$, uzunluğun $(50-60 \mathrm{~m})$ arasında olması uygun olmaktadır (Yağanoğlu 2013). Yüksel (1989), sera içerisinde alçak boylu bitkilerin yetiştirilmesi planlansa bile, sera yan duvar yüksekliğinin $1.80 \mathrm{~m}$ 'den, sebze yetiştirme seralarında ise 2.0 m'den az olmaması gerektiğini bildirmiştir. Yörede bulunan sera ve yüksek tünellerin enleri boyları ve yan duvar yükseklikleri büyük oranda bu kriterlere uygun olsa da ilde bulunan doğal havalandırmalı blok ve 60 metreden uzun seraların iklimlendirilmesi konusunda sorun yaşayacağı açıtır. İlde ileriki yıllarda kurulacak sera ve yüksek tünellerde uygun en ve boyların seçilmesi iklimlendirme nedeniyle ortaya çıkacak verim kayıplarının yaşanmaması açısından önemlidir.

Anket çalışması ile elde edilen İşletmelerde kullanılan yapı malzemeleri ve boyutsal özelliklerine ait bilgiler Çizelge 4'de verilmiştir. Seralar \% 60 bireysel sera olarak inşa edilirken blok sera olarak inşa edilen seraların \% 40 olduğu belirlenmiştir. Bireysel seraların uzun eksen yönü \% 33.33'ü kuzey-güney yönünde inşa edilirken \% 66.67'sinin doğu-batı yönünde kurulduğu görülmüştür. Blok olarak inşa edilen seraların ise \% 75'i kuzey-güney, \%25 i ise doğu-batı yönünde konumlandırılmıştır. Bireysel olarak inşa edilen yüksek tünellerin ise \%93.33 ünün doğu-batı yönlü olduğu 
görülmüştür. İncelenen bireysel ve blok seraların kuruluş yönlerinin bireysel seralarda doğu-batı, blok seraların ise kuzeygüney yönlü olmasının kış aylarında güneş ışınımdan daha fazla yararlanma açısından önemli olduğu belirlenmiştir. Seralar için günlük radyasyon toplamı $2300 \mathrm{Wh} \mathrm{m}^{-2}$ gün olmalıdır ve optimum bitki gelişimi için sınır değer ise $1000 \mathrm{Wh} \mathrm{m}^{-2}$ gün olarak kabul edilmektedir. Ayrıca Kasım, Aralık ve Ocak aylarındaki minimum güneşlenme süresi 500-550 saat olmalıdır (Baytorun ve ark. 1996; Zabeltitz 2011; Castilla ve Baeza, 2013). Kırşehir ilinde Aralık ve Ocak aylarında günlük toplam radyasyonun eşik değeri $2.3 \mathrm{kWh} \mathrm{m}^{-2}$ gün$^{-1}$ 'ün altında, sınır değer olan $1 \mathrm{kWh} \mathrm{m}^{-2}$ gün değerinin üstünde kaldığı ve Kasım, Aralık ve Ocak aylarındaki toplam güneşlenme süresi eşik değer olan 500-550 saatin altında olduğu bildirilmiştir (Boyacı ve ark. 2016). Seraların kuruluş yönüne dik esen şiddetli rüzgârlar devrilme ve örtü malzemesini parçalama yönünden etkili olur. Bunun önlenmesi amacıyla sera kısa eksenini rüzgârın esme yönüne inşa etmek gereklidir (Dökmen 1991). Kırşehir ilinde kurulan örtüaltı yapılarında, ışıklanma süresi ve toplam günlük radyasyon miktarı yetiştiricilik açısından kış aylarında yeterli düzeyde değildir. Bunun yanında uzun yıllık iklim verilerine göre Kırşehir ili için hakim rüzgâr yönü Kuzey’dir. Maksimum rüzgâr hızı ve yönüne bakıldığında güney güneybatı ve kuzey yönlü rüzgârların etkili olduğu görülmektedir. $\mathrm{Bu}$ nedenle kurulacak sera ve yüksek tünel yapılarının kısa kenarının bu yönlerde olması gerekmektedir. Ancak yetersiz 1şıklanmanın verim üzerine olumsuz etkisi düşünüldügünde ise ilde kurulması düşünülen sera ve yüksek tünellerin güneşten daha fazla yararlanabilmesi için uzun eksen yönünün Doğu-Batı yönünde konumlandırılması gerekmektedir. Şiddetli esen güney ve kuzey yönlü rüzgâr hılarının örtüaltı yapılarında devirme ve parçalama yönünden etkili olacağı dikkate alınarak rüzgar gergilerinin kullanılması ve bu yapıların kuzey ve güney yönlerine iç ortama ulaşan güneş 1şığını engellemeyecek şekilde rüzgâr kıranlar tesis edilmesi gerekmektedir.

Yörede incelenen seralarda plastik, polikarbon ve plastik+polikarbon kombinasyonlarının kullanıldığı görülürken, yüksek tünellerin tamamında polietilen (PE) plastik malzemenin kullanıldığı belirlenmiştir. İşletmelerde kullanılan yan duvar örtü malzemesi olarak seralarda polikarbon malzemenin yaygın olduğu çatıda ise polietilen plastik kullandığı ve UV ve IR gibi katk1 maddeli örtü malzemesi seçtikleri belirlenmiştir. Çiftçilerinin büyük bir çoğunluğu, sadece UV katkılı polietilen plastik yerine daha geniş kapsamlı olan $\mathrm{UV}+\mathrm{IR}+\mathrm{AF}+\mathrm{AV}$ katkılı polietilen örtüyü tercih etmeleri gerekmektedir (Emekli ve ark. 2007). Karasal iklime sahip yörede 1sı iletim kayıpları dikkate alındığında yan duvarlarda polikarbon, kasım, aralık ve ocak aylarında meydana gelen yetersiz 1şıklanma süresi ve toplam günlük radyasyon miktarı nedeniyle sera ve yüksek tünellerin doğu-batı yönünde konumlandırılması ve çatıda polietilen örtü malzemesinin kullanılması yetiştiricilik açısından önemlidir. Bunun yanında yapı içerisindeki 1sıyı tutmak için özellikle IR katk1lı örtü malzemesi ilde bulunan sera ve yüksek tünel işletmelerinde 1sıtma maliyetlerinin azaltılması bakımından oldukça önemlidir.

\subsection{Sera ve yüksek tünellerin iklimlendirilmesi}

Anket çalışması ile elde edilen Sera ve yüksek tünellerin iklimlendirilmesine ait bilgiler Çizelge 5 'de verilmiştir. İncelenen işletmelerin havalandırma sistemlerine bakıldığında genellikle ilk yatırım maliyeti düşük olan ve işletme gideri olmayan doğal havalandırma yönteminin uygulandığı

Çizelge 4. İşletmelere ait yapı bilgileri.

Table 4. Construction information for enterprises.

\begin{tabular}{|c|c|c|c|c|c|}
\hline \multirow{2}{*}{ İşletmelere ait yapı bilgiler } & \multirow{2}{*}{ Cevap Sinıfı } & \multicolumn{2}{|c|}{ Sera } & \multicolumn{2}{|c|}{ Yüksek tünel } \\
\hline & & Üretici sayısı & $\%$ & Üretici sayısı & $\%$ \\
\hline \multirow{4}{*}{ İşletmedeki yapı tipi } & Plastik Sera & 5 & 50.00 & 15 & 100.00 \\
\hline & Polikarbon & 2 & 20.00 & - & - \\
\hline & Polikarbon+Plastik Sera & 3 & 30.00 & - & - \\
\hline & Toplam & 10 & 100.00 & 15 & 100.00 \\
\hline \multirow{3}{*}{ Yerleşim şekli nassıldır } & Bireysel sera & 6 & 60.00 & 15 & 100.00 \\
\hline & Blok sera & 4 & 40.00 & - & - \\
\hline & Toplam & 10 & 100.00 & 15 & 100.00 \\
\hline \multirow{3}{*}{ Uzun eksen yönü } & Kuzey-Güney & 5 & 50.00 & 1 & 6.67 \\
\hline & Doğu-Batı & 5 & 50.00 & 14 & 93.33 \\
\hline & Toplam & 10 & 100.00 & 15 & 100.00 \\
\hline \multirow{5}{*}{ Konstrüksiyon şekli } & Çelik kafes kiriş sistem & 2 & 20.00 & - & - \\
\hline & Yay çatılı borulu sistem & 6 & 60.00 & 12 & 80.00 \\
\hline & Yay çatılı profil sistem & 2 & 20.00 & 2 & 13.33 \\
\hline & $\varnothing 8$ lik demir & & & 1 & 6.67 \\
\hline & Toplam & 10 & 100.00 & 15 & 100.00 \\
\hline \multirow{4}{*}{$\begin{array}{l}\text { Yapı elemanları birleştirme } \\
\text { yöntemi }\end{array}$} & Bulon (civata) & 4 & 40.00 & - & - \\
\hline & Kaynak & 2 & 20.00 & 2 & 13.33 \\
\hline & Bulon+Kaynak & 4 & 40.00 & 13 & 86.67 \\
\hline & Toplam & 10 & 100.00 & 15 & 100.00 \\
\hline \multirow{5}{*}{$\begin{array}{l}\text { Yan duvarlarda kullanılan örtü } \\
\text { malzemesi }\end{array}$} & Polietilen (normal) & 2 & 20.00 & - & - \\
\hline & Polietilen UV & 1 & 10.00 & 15 & 100.00 \\
\hline & Polietilen UV+IR & 2 & 20.00 & - & - \\
\hline & Polikarbon & 5 & 50.00 & - & - \\
\hline & Toplam & 10 & 100.00 & 15 & 100.00 \\
\hline \multirow{5}{*}{ Çatıda kullanılan örtü malzemesi } & Polietilen (normal) & 2 & 20.00 & - & - \\
\hline & Polietilen UV & 1 & 10.00 & 15 & 100.00 \\
\hline & Polietilen UV+IR & 4 & 40.00 & - & - \\
\hline & Polikarbon & 3 & 30.00 & - & - \\
\hline & Toplam & 10 & 100.00 & 15 & 100.00 \\
\hline
\end{tabular}


görülmüştür. Yörede doğal havalandırma yapan işletmelerde pencere alanının taban alanına oranı \% 3-16 arasında değiştiği belirlenmiştir. Ayrıca iki işletmede mekanik havalandırma sistemlerinin kullanıldığ 1 belirlenmiştir. Havalandırma açıklığ alanı taban alanına oranını araştırmacılar \% 18-25 olduğunu bildirmişlerdir (Nicolaus 1990; Zabeltitz 1990; Baytorun ve ark. 1994). Ülkemizde yapılan çalışmalar incelendiğinde, yaygın olarak doğal havalandırma yapıldığı ancak iyi bir havalandırma için pencere açıklıklarının taban alanına oranının çok düşük kaldığı bildirilmiştir (Saltuk 2005; Güllüler 2007; Emekli 2007; Çanakcı ve Akıncı 2007; Gale ve ark. 2014). Benzer olarak doğal havalandırmanın yaygın olduğu Kırşehir yöresinde, plansız yapılan seralarda hava çıkış açıklıklarının taban alanına oranının yetersiz kaldığı ve doğal havalandırmadan yeterince yararlanılamadığı görülmüştür.

İşletmelerin 1sıtma sistemleri incelendiğinde 1sıtma maliyetlerinin yüksekliği nedeniyle seraların \% 60'ında, yüksek tünellerin ise yaklaşık \%67'sinde 1sıtmanın yapılmadı̆̆ belirlenmiştir. Isıtma yapan toplam 9 adet işletmenin 8 inde fosil yakıtlarla isıtma yapıldığı ve maliyetlerinin yüksekliği nedeniyle ancak bitkileri don tehlikesinden korumak amaciyla 1sıtma yapılabildiği belirlenmiştir. İlde bulunan jeotermal kaynaklardan sera 1sıtması amacıyla Çiçekdağı ilçesinde bulunan bir işletmenin faydalandığı ve 1sıtmayı verim arttırmak amacıyla yaptıkları belirlenmiştir. Yapılan çalışmalarda ülkemizde yaygın olarak 1sitmanın don tehlikesinden korunmaya yönelik sobalı 1sıtma, yağmurlama ile dondan koruma ve bu iki yöntemin kombinasyonu ve azda olsa merkezi 1sıtma yapıldı ğ belirtilmiştir (Çanakc1 ve Akıncı 2007; Emekli ve ark. 2007; Gale ve ark. 2014). Jeotermal enerjili isitma sistemlerinin kullanımının fosil yakıtlara göre ekonomik açıdan önemli avantaj sağlayacağını ve jeotermal enerji kullanımın mümkün olduğu yerlerde sera tesis edilmesi, yöre halkına ve ülke ekonomisine önemli katkılar sağlayacağını ifade etmişlerdir (Kelkit ve Bulut 1998; Eltez ve Eltez 2005; Karataş ve Durdu 2013). Benzer olarak yörede fosil yakıtlar ile 1sıtma bedelinin yüksek olması nedeniyle 1sıtmanın don tehlikesinden korunmak amaciyla yapıldığ 1 ve ilde bulunan jeotermal

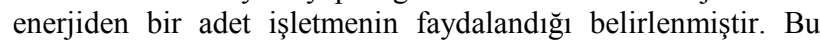
işletmede il özel idaresinden kiralanan ve sera 1sıtması için kullanılan jeotermal suyun debisi $1201 \mathrm{sn}^{-1}$ ve giriş sıcaklığı $80{ }^{\circ} \mathrm{C}$, su çıkış sıcaklığı ise ortalama $40^{\circ} \mathrm{C}$ dir. Bu işletmede ucuz enerji kaynağının yanında yıl boyu üretim imkânı nedeniyle verimde önemli artışların kaydedildiği belirlenmiştir. Kullanımı ucuz fakat ilk yatırım maliyetleri yüksek olan jeotermal enerjinin küçük ölçekli işletmelerde kullanılması mümkün olmadığı yapılan anket çalışması sonucu belirlenmiştir. Bunun nedeni ilk yatırım maliyetleri arasında yer alan jeotermal su iletim hattı borularının yatırım bedelinin yaklaşık $1000000 \mathrm{TL} \mathrm{km}^{-1}$ olmasıdır. Aynı zamanda gelen suyun kuyulara reenjeksiyonu için dönüş hattı boru fiyatlarının da bu rakama ilave edilmesi düşünüldüğünde küçük ölçekli işletmelerin bu altyapı maliyetlerini karşılamasının mümkün olmadığı görülmektedir. Bu kaynakların yetkili makamlarca yöre çiftçisinin kullanımına sunulması için altyapı maliyetlerinin karşılanması yörede jeotermal seracılığın yaygınlaştırılması açısından oldukça önemlidir.

İncelenen işletmelerin serinletme sistemlerine bakıldığında büyük bir oranda serinletme yapılmadığı görülmüştür. Bunun nedenleri arasında serinletme yöntemlerinin 1sıtma yöntemleri kadar bilinmemesi ve bu yöntemleri bilen küçük aile işletmelerinin ise bunun işletmeye ek maliyet getirecek olması nedeniyle kullanmadığı belirlenmiştir. Yörede serinletme sistemlerini kullanan işletmelerin yıl boyu üretim yapan büyük işletmeler olduğu bunlardan birinin Kaman ilçesinde ceviz kooperatifine ait olan ve fidan yetiştiriciliği yapan işletmede düşük basınçlı sisleme sistemi ve $(120 \times 120 \mathrm{~cm})$ havalandırma fanlarının kullanıldığ 1 belirlenirken, Çiçekdağ 1 ilçesinde bulunan bir adet modern serada ise yüksek basınçlı sisleme sistemi ve havalandırma fanların kullanıldığı belirlenmiştir. İlde bulunan seraların \%70 inde çeşitli gölgeleme malzemelerinin kullanıldığı belirlenmiştir. Yüksek tünel işletmelerinin ise yalnızca birinde dıştan gölgeleme malzemesi kullandığ belirlenmiştir. Emekli (2007) seraların aşırı 1sınmasını önlemek amacıyla kireç veya boyayı sera dış yüzeyine püskürterek sürekli veya kısa süreli olarak gölgeleyen materyaller kullanıldığını, Boyacı ve ark. (2017) ise mekanik havalandırma ile ulaşılan sera içi sıcaklık değerleri en fazla $5-6^{\circ} \mathrm{C}$, gölgeleme ile $6{ }^{\circ} \mathrm{C}$, fan ped sistemi ile $15{ }^{\circ} \mathrm{C}$, yüksek basınçlı sistemler ile $8{ }^{\circ} \mathrm{C}$ ve sera çatısından yapılan serinletmede $5-6^{\circ} \mathrm{C}$ daha düşük olabileceğini belirtmişlerdir. Mekanik serinletme yöntemleri doğal havalandırma ve gölgeleme yöntemlerine göre işletilmesi maliyet gerektiren bir yöntemdir. Yaz aylarında yapılan örtüaltı üretiminin açıkta yapılan yetiştiricilik ile aynı döneme denk gelmesi yetiştirilen ürünlerin fiyatlarını düşürmektedir. Bu yüzden mekanik yöntemlerin uygulandığı işletmelerde enerji maliyetinin üretim maliyeti içerisindeki payının iyi hesap edilmesi gerekmektedir.

\subsection{Yetiştiriciliğe ait bilgiler}

Anket çalışması ile elde edilen yetiştiriciliğe ait bilgiler Çizelge 6'te verilmiştir. İlde örtüaltı tarımının çokta eski olmamasına rağmen Merkez, Kaman ve Çiçekdağı ilçelerinde sera ve yüksek tünel işletmelerinde başta domates olmak üzere biber, salatalık, fasulye, marul roka, tere gibi birçok sebze ürünü yanında Kaman ilçesinde fide ve ceviz fidanı üretiminin olduğu belirlenmiştir. İlde bulunan Ahi Evran Üniversitesi Ziraat Fakültesi bünyesinde bir adet araştırma serası ve Çiçekdağ ilçesinde bulunan serada sebze yetiştiriciliği yanında araştırma serası olarak kullanılan bir seranın mevcut olduğu ve içerisinde yetiştirme tekniği ve işletmeye ait çeşit çalışmalarının yapıldığ belirtilmiştir. İlde bulunan sera ve yüksek tünel işletmelerinde sırasıyla \% 50 ve yaklaşık \% 74 oranında topraklı tarım yapıldığı belirlenmiştir. Tüplerde yetiştiriciliğin ise ilin Kaman ilçesinde bulunan kooperatif seralarında tüplü ceviz fidanlarının yetiştirildiği bunun yanında erkencilik amacıyla serasında fide yetiştirip açık tarlasına dikim yapan işletmelerinde bulunduğu belirlenmiştir. Serik bölgesinde yapılan modern yetiştiricilikte üreticilerin \% 87.5'inin perlit, \% 12.5 inin kayayünü kullandığı belirlenmiştir. İlde bulunan topraksız tarım işletmelerde ise ürün yetiştirme ortamı olarak kokopit kullanıldı̆̆ belirlenmiştir. Tüzel ve ark. (2010) tarafından Antalya ilinin Serik ilçesinde yapılan çalışmada modern seraların tamamında bombus arı kullanımı varken geleneksel seralarda bombus arılarının kullanımının yaygın olmadığını bildirmiştir. İlde mevcut seralarda \% 60, yüksek tünellerin ise tamamında tozlaşma amacıyla herhangi bir işlem yapılmadığı belirlenmiştir. İlde modern anlamda üretim yapan üç işletmede tozlaşmanın bombus arısı ile yapıldığı ve havalandırma açıklıklarında arıların çıkışını önlemek amacıyla böcek tülü kullandıkları belirlenmiştir.

Geleneksel sera üreticilerinin dekara 5 ton kadar çiftlik gübresi uygularken kimyasal gübre olarak amonyumlu ve potasyumlu gübreler kullanmaktadırlar (Tüzel ve ark. 2010). İlde organik gübre olarak koyun ve büyükbaş hayvan gübresi kullanımının yaygın olduğu ve dikimden önce toprağa karıştırıldığı bunun yanında kimyasal gübre olarak amonyumlu ve potasyumlu gübreler kullandığı belirlenmiştir. 
Çizelge 5. Sera ve yüksek tünellerin iklimlendirilmesi.

Table 5. The acclimatization of greenhouses and high tunnels.

\begin{tabular}{|c|c|c|c|c|c|}
\hline \multirow{2}{*}{ İklimlendirme bilgileri } & \multirow{2}{*}{ Cevap Sınıfı } & \multicolumn{2}{|c|}{ Sera } & \multicolumn{2}{|c|}{ Yüksek tünel } \\
\hline & & Üretici sayısı & $\%$ & Üretici sayısı & $\%$ \\
\hline \multirow{3}{*}{ Havalandırma şekli } & Doğal havalandırma & 8 & 80.00 & 15 & 100.00 \\
\hline & Doğal+Mekanik havalandırma & 2 & 20.00 & - & - \\
\hline & Toplam & 10 & 100.00 & 15 & 100.00 \\
\hline \multirow{7}{*}{ Gölgelendirme şekli } & Kireçle badana yaparak & 1 & 10.00 & - & - \\
\hline & Is1 perdesiyle & 1 & 10.00 & - & - \\
\hline & Gölgeleme tülü & 3 & 30.00 & 1 & 6.67 \\
\hline & Kireç+diştan örterek & 1 & 10.00 & - & - \\
\hline & Mermer tozu & 1 & 10.00 & - & - \\
\hline & Gölgeleme yapılmıyor & 3 & 30.00 & 14 & 93.33 \\
\hline & Toplam & 10 & 100.00 & 1 & 100.00 \\
\hline \multirow{4}{*}{ Isıtma hangi amaçla yapılmaktadır } & Dondan koruma & 3 & 30.00 & 5 & 33.33 \\
\hline & Bitki istekleri & 1 & 40.00 & - & - \\
\hline & Isitma yapilmiyor & 6 & 60.00 & 10 & 66.66 \\
\hline & Toplam & 10 & 100.00 & 15 & 100.00 \\
\hline \multirow{7}{*}{ Isıtmada kullanılan yakıt türü } & Jeotermal & 1 & 10.00 & - & - \\
\hline & Kömür & 1 & 10.00 & 1 & 6.67 \\
\hline & Kömür+odun & 1 & 10.00 & - & - \\
\hline & Kömür+motorin & 1 & 10.00 & - & - \\
\hline & Tüpgaz & - & - & 4 & 66.66 \\
\hline & Isitma yapilmiyor & 6 & 60.00 & 10 & - \\
\hline & Toplam & 10 & 100.00 & 15 & 100.00 \\
\hline \multirow{3}{*}{ Serinletme yapılıyor mu } & Evet & 2 & 20.00 & 1 & 6.67 \\
\hline & Hayır & 8 & 80.00 & 14 & 93.33 \\
\hline & Toplam & 10 & 100.00 & 15 & 100.00 \\
\hline
\end{tabular}

Çizelge 6. Yetiştiriciliğe ait bilgiler.

Table 6. Information belonging to cultivation.

\begin{tabular}{|c|c|c|c|c|c|}
\hline \multirow{2}{*}{ Yetiştiriciliğe Ait Bilgiler } & \multirow{2}{*}{ Cevap Sinıfi } & \multicolumn{2}{|c|}{ Sera } & \multicolumn{2}{|c|}{ Yüksek tünel } \\
\hline & & Üretici sayısı & $\%$ & Üretici sayısı & $\%$ \\
\hline \multirow{5}{*}{$\begin{array}{l}\text { Yapılma amacı (yararlanma şekli) } \\
\text { nedir }\end{array}$} & Sebze üretimi & 5 & 50.00 & 11 & 73.33 \\
\hline & Araştırma Seraları & 2 & 20.00 & - & - \\
\hline & Fidan & 2 & 20.00 & - & - \\
\hline & Fide & 1 & 10.00 & 4 & 26.67 \\
\hline & Toplam & 10 & 100.00 & 15 & 100.00 \\
\hline \multirow{4}{*}{ Ürün yetiştirme ortamı nedir } & Topraksız & 3 & 30.00 & - & - \\
\hline & Topraklı & 5 & 50.00 & 11 & 73.33 \\
\hline & Tüplerde & 2 & 20.00 & 4 & 26.67 \\
\hline & Toplam & 10 & 100.00 & 15 & 100.00 \\
\hline \multirow{4}{*}{ Yetiştiricilik şekli } & Tek ürün yetiştiriciliği & 5 & 50.00 & 1 & 6.67 \\
\hline & İlkbahar yetiştiriciliği & - & - & 4 & 26.67 \\
\hline & İlkbahar+Sonbahar yetiştiriciliği & 5 & 50.00 & 10 & 66.67 \\
\hline & Toplam & 10 & 100.00 & 15 & 100.00 \\
\hline \multirow{4}{*}{ Tozlaşma nasıl sağlanıyor } & Bambus arıs1 & 3 & 30.00 & - & - \\
\hline & Vibrasyon & 1 & 10.00 & - & - \\
\hline & Doğal & 6 & 60.00 & 15,00 & 100,00 \\
\hline & Toplam & 10 & 100.00 & 15 & 100.00 \\
\hline \multirow{5}{*}{ Ne tür gübre kullanıyorsunuz } & Organik & 4 & 40.00 & 11 & 73.33 \\
\hline & Kimyasal & 4 & 40.00 & 4 & 26.67 \\
\hline & Organik+Kimyasal & 1 & 10.00 & - & - \\
\hline & Yok & 1 & 10.00 & - & - \\
\hline & Toplam & 10 & 100.00 & 15 & 100.00 \\
\hline
\end{tabular}

Isıtma ve serinletme maliyetlerinin getireceği ek maliyetler göz önüne alınarak işletmelerin tek ürün veya çift ürün yetiştiriciliğini benimsediği, Tek ürün yetiştiriciliği yapan modern seralar tüm yıl boyunca üretim yapmakta ve daha fazla verim alabilmekteyken çift ürün yetiştiriciliği yapan üreticilerin ekolojik isteklerden önce yetiştiricilik tecrübelerinin ve yeterli 1sıtma sistemleri olmadıkları için çift ürün yetiştiriciliği yaptığ 1 belirlenmiştir. Yörede önceki çalışmalara benzer olarak 1sıtma maliyetlerinin yüksek olması nedeniyle çift ürün yetiştiriciliğinin yaygın olduğu belirlenmiştir (Çanakcı ve Akınc1 2007; Emekli ve ark. 2007; Tüzel ve ark. 2010; Gale ve ark. 2014). Oysaki ilde mevcut jeotermal kaynakların seracılıkta kullanılması ile ilin iç pazara olduğu kadar ihracata katkı yapacak potansiyeli vardır. Ancak ilde bu potansiyeli harekete geçirecek dinamikler henüz oluşmadığından yörenin sahip olduğu örtüaltı potansiyeli yıllar itibariyle artış göstersede beklenen düzeyde olmadığı söylenebilir. 


\section{Sonuç}

Kırşehir ilinde sera ve yüksek tünel işletmelerinin yetiştiricilik süreleri göz önüne alındığında henüz yeni oldukları, işletmelerin plansız ve projesiz yapıları piyasadan aldıkları ve çevreden görerek herhangi bir demirci ustasına inşa ettirdikleri ve uzman kişilerden yardım almadıkları belirlenmiştir. İlde yeni başlayan örtüaltı faaliyetlerinin uzun vadede yapısal olarak ortaya çıkacak sorunların önüne geçilebilmesi amacıyla alınacak tedbirler ileriki yıllarda verim kayıplarının azaltılması bakımından önemlidir.

İlde UV katkılı malzemenin kullanılması örtü malzemesinin dayanımı açısından uygun olsa da, karasal iklime sahip ilde IR katk1lı plastikler, 1s1 perdeleri ve bireysel yapilar yerine blok yapıların inşa edilmesi ısı korunumu açısından önemlidir.

Çiçekdağı ilçesinde bulunan bir adet 180 dekarlık sera işletmesi ilin en büyük ve tek modern işletmesidir. Bu işletmede 1sıtma jeotermal enerji ile sağlanmaktadır. İşletmede çalışan mühendis, teknisyen ve sürekli işçiler ile birlikte yaklaşık 200 kişilik istihdam yaratmakta ve yurt içi olduğu kadar yurt dışına da ürün pazarlayarak yöre ve ülke ekonomisine büyük katkılar sağlamaktadır. Jeotermal enerjinin sağladığı ucuz enerji ile yıl boyu yetiştiriciliğin mümkün olduğu ilde modern sera işletmelerinin yaygınlaştırılması amacıyla hibe ve teşviklerin verilmesinde yöre üreticisine kolaylıklar sağlanması ve yörede organize sera bölgelerinin kurulması örtüaltı tarımının geliştirilmesi açısından oldukça önemlidir.

Anket yapılan işletmelerde üreticilerin sera yapılarını arttırmak isteğinde oldukları ancak karşılaştıkları sorunlar arasında; arazi yetersizliği, kalifiye işgücü ve sermaye azlığ gelmektedir. Ayrıca yörede küçük aile ișletmelerinin jeotermal kaynaklardan yararlanmak istediklerini ancak sermaye yetersizliği ile bu enerji kaynaklarından yararlanmalarının ilk yatırım maliyetleri bakımından mümkün olmadığı belirlenmiştir. $\mathrm{Bu}$ nedenle jeotermal enerjinin ilk yatırım maliyetlerinin yetkili kurum ve kuruluşlarca sağlanarak yöre üreticisinin kullanımına kullanım bedeli karşılığında sunulması yörede sera aktivitesinin artması ve yörenin seracılıkta cazibe merkezi haline getirilebilmesi için oldukça önemlidir.

\section{Teşekkür}

$\mathrm{Bu}$ çalışma, Kırşehir Ahi Evran Üniversitesi bilimsel araştırma projeleri koordinasyon birimi tarafindan ZRT.A4.17.003 nolu proje ile desteklenmiştir.

\section{Kaynaklar}

Baytorun AN, Tokgöz H, Üstün S, Akyüz A (1994) Seralarda iklimlendirme olanakları. 3. Soğutma ve İklimlendirmeKongresi, Bildiriler Kitab1, 4-6 Mayıs, Adana, s. 303-313.

Boyacı S, Akyüz A, Üstün S, Baytorun AN, Çaylı A (2016) Kırşehir ilinin örtüaltı tarım potansiyelinin belirlenmesi. Nevşehir Bilim ve Teknoloji Dergisi 5(2): 142-157.

Boyacı S, Akyüz A, Üstün S, Baytorun AN, Güğercin Ö (2017) seralarda yüksek sıcaklıkların azaltılmasında kullanılan yöntemler. Türkiye Tarımsal Araştırmalar Dergisi 4(1): 89-95.

Çanakcı M, Akıncı İ (2007) Antalya ili seralarında kullanılan havalandırma ve 1sitma sistemleri. Akdeniz Üniversitesi Ziraat Fakültesi Dergisi 20(2): 241-252.

Dökmen F (1991) Yalova - Karamürsel Sahil Şeridindeki Bazı Seralarda Havalandırma Sistemlerinin Yeterlilikleri Üzerine Bir Araştırma. Yüksek Lisans Tezi, Uludağ Üniversitesi Fen Bilimleri Enstitüsü, Bursa.
Dökmen F, Arıcı İ. (1998) Yalova ve yöresinde sera havalandırma sistemlerinde rüzgâr etkisi üzerine bir araştırma. Atatürk Üniversitesi Ziraat Fakültesi Dergisi 29(2): 304-319.

Eltez S, Eltez RZ (2005) Bergama ve Dikili ilçeleri (İzmir) sera potansiyeli ve seracılık faaliyetleri üzerine bir araştırma. Ege Üniversitesi Ziraat Fakültesi Dergisi 42(2): 203-214.

Emekli NY (2007) Antalya ili Kumluca ilçesindeki seraların teknik ve yapısal yönden incelenmesi. Yüksek Lisans Tezi, Akdeniz Üniversitesi Fen Bilimleri Enstitüsü, Antalya.

Emekli NY, Baştuğ R, Büyüktaş K (2007) Antalya ili Kumluca ilçesindeki seraların mevcut durumu, sorunları ve uygun çözüm önerilerinin geliştirilmesi. Akdeniz Üniversitesi Ziraat Fakültesi Dergisi 20(2): 273-288.

Gale U, Tüzel Y, Öztekin GB (2014) Antalya'nın Kepez ilçesinde geleneksel sera üretiminin özellikleri. Türkiye Tarımsal Araştırmalar Dergisi 1: 68-77.

Güllüler F (2007) Adana ili ve ilçelerindeki seraların yapısal özelliklerinin incelenmesi ve T.S.E standartlarına uygunluğunun araştırılması. Yüksek Lisans Tezi, Çukurova Üniversitesi Fen Bilimleri Enstitüsü, Adana.

Kadıoğlu Y (2013) Simav'da jeotermal seracılık. Marmara Coğrafya Dergisi 28: 64-80.

Karataş BS, Durdu ÖF (2013) Aydın ili koşullarında sera ısıtmasında jeotermal enerjinin kullanılabilirliğinin incelenmesi. Ege Üniversitesi Ziraat Fakültesi Dergisi 50(1): 47-56.

Kelkit A, Bulut Y (1998) Seralarda süs bitkileri yetiştiriciliğinde jeotermal enerjinin önemi. Ekoloji Çevre Dergisi 8(29): 21-24.

Nicolaus A (1990) Ventilation methodologies in greenhouses. Acta Horticulturae, 263(1): 299-306.

Saltuk B (2005) Mersin ili ve ilçelerinde bulunan plastik seraların yapısal yönden incelenmesi ve gelistirilme olanakları üzerine bir araştırma. Yüksek Lisans Tezi, Çukurova Üniversitesi Fen Bilimleri Enstitüsü, Adana.

Sevgican A (1989) Örtüaltı Sebzeciliği. Tarımsal Araştırmaları Destekleme ve Geliştirme Vakfi, Yayın No: 19, Yalova.

Sevgican A, Tüzel Y, Gül A, Eltez R.Z (1990) Türkiye'de Örtüaltı Yetiştiriciliği. V. Türkiye Ziraat Mühendisleri Teknik Kongresi Cilt 2, Ankara, s. 679-707.

TÜIK (2017) Bölgesel istatistikler. https://biruni.tuik.gov.tr/bolgeselistatistik/ sorguGiris.do. Erişim 20 Kasim 2017.

Tüzel Y, Öztekin GB, Karaman İ (2010) Serik ilçesindeki modern ve geleneksel sera işletmelerinin üretici özellikleri, sera yapısı ve sebze üretim teknikleri bakımından karşılaştırılması. Ege Üniversitesi Ziraat Fakültesi Dergisi 47(3): 223-230.

Üstün S, Baytorun, A.N (2003) Sera projelerinin hazırlanmasına yönelik bir uzman sistemin oluşturulması. KSÜ Fen ve Mühendislik Dergisi 6(1): 168-176.

von Elsner B, Briassoulis D, Waaijenberg D, Mistriotis A, von Zabeltitz C, Gratraud J, Russo G, Suay-Cortes R (2000) Review of structural and functional characteristics of greenhouses in european union countries: Part I, design requirements. Journal of Agricultural Engineering Research, 75: 1-16.

Yağanoğlu V (2013) örtüaltı yapıları. Atatürk Üniversitesi Ziraat Fakültesi Yayınları, Erzurum.

Yüksel AN (1989) Sera Yapım Tekniği. Hasad Yayıncılık Ltd. Şti., İstanbul.

Zabeltitz C (1990) Greenhouse construction in function of beter climate control. Acta Horticulturae 263(1): 357-374. 